Relations industrielles

Industrial Relations

\title{
Adaptation and Innovation in Wage Payment Systems in Canada, by Jack Chernik, Study no 5, Task Force on Labour Relations, Ottawa, Privy council office, 1970, 130 pp.
}

\section{Sidney H. Ingerman}

Volume 26, numéro 1, 1971

URI : https://id.erudit.org/iderudit/028198ar

DOI : https://doi.org/10.7202/028198ar

Aller au sommaire du numéro

Éditeur(s)

Département des relations industrielles de l'Université Laval

ISSN

0034-379X (imprimé)

1703-8138 (numérique)

Découvrir la revue

Citer ce compte rendu

Ingerman, S. H. (1971). Compte rendu de [Adaptation and Innovation in Wage Payment Systems in Canada, by Jack Chernik, Study no 5, Task Force on Labour Relations, Ottawa, Privy council office, 1970, 130 pp.] Relations industrielles / Industrial Relations, 26(1), 241-244. https://doi.org/10.7202/028198ar

Tous droits réservés @ Département des relations industrielles de l'Université Laval, 1971
Ce document est protégé par la loi sur le droit d'auteur. L’utilisation des services d’Érudit (y compris la reproduction) est assujettie à sa politique d'utilisation que vous pouvez consulter en ligne.

https://apropos.erudit.org/fr/usagers/politique-dutilisation/ 


\section{RECENSIONS}

Syndicalisme, consommation et société de consommation, par Bernard Solasse, Etude no 3, Equipe spécialisée en relations de travail, Ottawa, Bureau du Conseil privé, 1968, 47 pages.

Bernard Solasse qui fut un certain temps conseiller auprès de la Confédération des syndicats nationaux, était bien placé pour aborder le sujet de cette étude. L'auteur le précise dans son introduction: c'est une étude de cas qui porte sur l'action et les prises de position de la CSN dans le domaine de la consommation.

Cette étude est antérieure aux décisions des gouvernements de protéger les consommateurs dans les limites de certaines lois. Bernard Solasse a donc dû puiser là où les renseignements étaient disponibles. Il s'est largement inspiré de l'aide apportée par le Service du budget familial de la CSN.

L'action de cette centrale syndicale dans le domaine de la consommation part du résultat de trois facteurs, selon M. Solasse :

1-l'endettement croissant des syndiqués et des salariés en général ;

2-l'amélioration du pouvoir d'achat des syndiqués et d'une façon plus générale, des salariés-consommateurs ;

3-le dynamisme agissant et mobilisateur d'une forte personnalité, André Laurin, dont le travail que ce dernier accomplit à la CSN depuis 1962 a fortement inspiré l'auteur.

Les objectifs poursuivis par la CSN, seule ou en collaboration avec d'autres organismes, peuvent se regrouper, selon $M$. Solasse, autour de ces quatre thèmes majeurs :

1 - l'aide qui est essentiellement l'assistance juridique aux syndiqués et aux salariés endettés;

2-l'information et l'éducation du syndiqué et du consommateur;

3-l'amélioration du pouvoir d'achat du consommateur; 4-l'action politique visant à la fois l'opinion publique et les différents niveaux de gouvernements.

M. Solasse constate qu'une étude de cas, «en surcroît descriptive », se prête mal aux généralisations théoriques.

Cette étude a été préparée au moment où le service que dirige M. Laurin obtenait ses plus grands succès. Il serait à souhaiter que l'étude soit complétée et pour certaines questions, approfondie, pour savoir, par exemple, s'il est vrai et dans quelle mesure, M. Laurin a réussi à susciter et affermir la prise de conscience du syndiqué-consommateur.

Il est indéniable que les divers organismes non syndicaux qui ont fait l'éducation et l'information du consommateur ont éveillé l'attention du citoyen qui était aux prises avec des difficultés économiques très grandes. Ces organismes sont les Associations coopératives d'économie familiale (ACEF), les Caisses d'économie, les magasins Coop.

En somme, M. Solasse a tracé le programme d'une plus vaste étude qui pourrait être non seulement intéressante pour les chercheurs, mais essentielle dans une société qui ne peut plus se définir autrement que par ces deux mots déjà familiers : société de consommation.

Jacques LAFRENIERE

Adaptation and Innovation in Wage Payment Systems in Canada, by Jack Chernik, Study no 5, Task Force on Labour Relations, Ottawa, Privy council office, 1970, $130 \mathrm{pp}$.

Firms can be expected to adapt their wage payment system to the changing economic environment in which they function. In the present period in Canadian economic development the nature of technical advances, trade union attitudes and government economic and industrial relations policies provide the most important influences determining this environment. Professor Jack Cher- 
nick in his Task Force on Labour Relations, Study No. 5, ADAPTATION AND INNOVATION IN WAGE PAYMENT SYSTEMS IN CANADA examines the extent and importance of changes in methods of wage payment in the post-war period. He uses as background for this study developments in the United States. After discussing the role of traditional and innovative wage payment methods the author speculates on the possibility of a conscious national policy to promote alteration of wage payment schemes as an adjunct to government efforts to raise productivity and reduce inflationary pressures in the Canadian economy.

Chapter I introduces the main line of argument and the methodological approach of the study. Chapters II-IV are entitled: Incentives In Compensation Systems; Sharing Productivity Gains ; Profit-Sharing, and ; Profit-Sharing Implications and Prospects. Chapter VI presents a summary and the conclusions of the Study. A resume of each of the six chapters in French appears in a concluding appendix.

A discussion of the rational for individual and small group piece-work incentive plans, followed by a brief explanation of the operation of these plans is the subject matter that begins chapter II. These plans have traditionally been the most widely used incentive schemes found in manufacturing. Two related questions are then dealt with : in the period under study has there been a change in the relative importance of these incentive plans? and ; will Canadian industry have marked difficulties in adapting its wage payment systems to evolving production technology? These particular questions are considered important given the assumption that industrial growth in the present period is characterized by large investments in equipment embodying techniques (for example, automation) not amenable to individual and small group incentives.

Professor Chernick maintains that there is little evidence of adaptation of incentive systems, and because there is a lower level of use of incentive plans in Canada than the United States «adjustments to new conditions of mechanization in Canada will be less serious than that in the United States». However, while both of these conclusions may be intuitively plausible the data presented to support them is less than satisfactory. The relatively constant proportion of workers on all incentive plans in the United States referred to as evidence could be consistent with a situation in which small group incentive plans are being replaced or phased out as large group or plant wide incentive payment systems are being adopted. (Large group or plant wide incentive plans usually associated with more integrated production processes are discussed in Chapter III). Further, the difficulty of adaptation of a particular work payment system is largely dependent on the conditions under which it is introduced. As the study so excellently points out in discussing Canadian Westinghouse's conversion of an existing piece-work system to a day-work (hourly wage), system, conversion of an existing system is a complex and costly affair. However, where entirely new production units are organized implementation of an appropriate wage payment scheme is more routine. Thus judgments about the relative ease or difficulty of adapting wage payment systems to changing technology should attempt to take account of the extent to which already functioning production units require change as compared to adaptations in new units. Such a discussion would have strengthened this and the subsequent chapter.

The latter sections of Chapter II consider the extent and usefulness of plans to convert hourly paid workers to salaried status. Firms usually make this change with the expectation that additional benefits and status associated with payment by salary will improve worker motivation and lower labour turnover. Unions have from time to time asked for salary status because it implies, among other things, steadier work and longer periods of notification before layoff. It also typically provides for sick leave with pay; a benefit usually not available to hourly paid workers.

The conclusion of this investigation is that in the United States «there has ... been some movement... toward giving blue collar workers the status of salaries employees ». But, for the most part, this has occurred in special cases where blue collar workers are in technical or experimental jobs that require close con- 
tact with engineers or other white collar employees, or where salaried status is granted as a device to counteract potential union organization. Thus, the study finds that in the United States salary status has been given mainly to non-union employees despite the well advertised but lightly pressed formal demand for salary status made by the United Automobile Workers (UAW) in its 1967 negotiations with General Motors.

Insufficient data is available to evaluate similar trends in Canada. However, Professor Chernick describes the interesting case of the Kingston, Ontario plant of the Aluminum Company of Canada which put approximately 1500 hourly rated workers on weekly salary in 1966.

A major change in the Canadian wage payment system which might have been explored at this juncture of the study is the large increase in fringe benefit payments as a percentage of total payrolls. A recent study by Thorne Group Limited of Toronto based management consulting firm estimates, using a crosssection of 115 employers with 366,637 employees, that fringe benefits as a percentage of total payroll rose from 23.1 per cent in 1965 to 27.9 per cent in 1969. Why has this happened ? Will this trend continue? How will these changes affect firm and union decision making? Unfortunately, this entire topic is never mentioned.

The intent of Chapter III is to describe attempts to increase labour productivity through large group or plant-wide incentive plans. In fact the chapter is a general appraisal of union and management responses to the problems of introducing technical change and in sharing its benefits. The author's conclusion is that there is little evidence of major changes in Canadian wage payment systems designed specifically to motivate technical innovations and share the resulting gains. Despite high sounding pronouncements by management and union officials about dramatic changes resulting from automation, Professor Chernick reveals that collective bargaining agreements have made mainly piecemeal adaptations to technical change. Indeed, in an analysis of over 1,000 collective agreements in force in Ontario in 1967 the study shows that only 31 per cent contained provisions governing technological change and of these only three agreements had provisions for workers and management sharing in the gains of productivity by specifically relating improved efficiency to wage rates or income.

The 1963 agreement between the British Columbia Maritime Employer's Association and the International Longshoremen's and Warehousemen's Union (Canadian Area) is cited as one the few major unified approaches. In this case the parties negotiated an 'automation protection plan' which guaranteed the then existing longshore work force 1820 hours per year of work opportunity or equivalent wages as well as other benefits in exchange for cooperation in introducing new machinery and abandoning certain archaic work rules.

Since the publication of this Task Force study, Canadian west coast longshoremen and stevedore firms under contact with Kaiser in the port of Roberts Bank near New Westminster, British Columbia have designed a unique contractual arrangement. Longshoremen operating a new highly mechanized facility loading coal for Japan are all guaranteed permanent work and a monthly salary over the life of the contact. They are all paid the same salary; all are responsible for all skilled tasks; all share shift work on a rotational basis. In 1972 each one of these workers will receive a monthly salary of $\$ 1,096.20$ or $\$ 51$ a day for a standard eight hour shift.

Despite the above examples, totally new concepts of wage payment are scarce. Undoubtedly as scarce as totally new productive techniques.

A primer on various types of profit sharing plans is presented in Chapter IV. This is followed by standard arguments about the value of profit sharing plans as a motivational device. The reader will discover that few Canadian firms use profit sharing plans, where they are used they typically are in a deferred payment form in order to provide a substitute for pension plans, and finally most plans are for executives rather than for the work force in general. In addition, with minor exceptions, unions are opposed to the introduction of these plans.

Chapter V reveals that some people believe that complex problems like 
worker alienation, income maldistribution, and inflation can be solved by expanding profit sharing schemes as a matter of government policy. No convincing argument is made for any of these propositions. In concluding the chapter Professor Chernick describes the failure of the French government in using a national policy of profit sharing promotion as part of a programme to reduce class antagonism and increase worker productivity.

ADAPTATION AND INNOVATION IN WAGE PAYMENT SYSTEMS IN CANADA can be recommended as a study which brings together descriptions of existing wage payment systems and describes the few publicized cases where Canadian firms and unions have introduced innovations in order to cope with new circumstances and technology. Its weakness lies in the fact that in trying to be all inclusive it fails to provide insights into the relation between the nature of the evolution of key industries and sectors of the economy and the particular kinds of pressures that have been created for wage payment adaptation. If this had been done it might have been possible to examine the ways in which institutional structures dealt with these pressures in the past and what can be expected of them in the future. Such an approach might also have provided more methodological guidance for researchers who will follow Professor Chernick's pathbreaking effort.

\section{Sidney H. INGERMAN}

Le syndicalisme au Québec: structure et mouvement, par MM. J. Dofny et P. Bernard, Etude no 9, Equipe spécialisée en relations du travail, Ottawa, Bureau du Conseil privé, 1968, 117 pp.

L'Equipe spécialisée en relations du travail se devait d'étudier d'une façon plus particulière le «syndicalisme au Québec », au même titre qu'elle l'a fait pour connaître mieux le genre de syndicalisme qui se pratique dans certains pays. Le Québec se singularise ... aussi par son syndicalisme!

Les têtes de chapîtres nous laissent déjà entrevoir combien cette étude sera intéressante : groupe de pression et mou- vement social; les modalités d'action du mouvement social et du groupe de pression; l'exemple du syndicalisme américain; l'évolution historique du syndicalisme au Québec; ancien syndicalisme, syndicalisme moderne et nouveau syndicalisme; les causes des principaux changements structurels des appareils syndicaux ; modèles de relations industrielles et tendances du syndicalisme québécois.

Les auteurs insistent d'abord pour faire la distinction entre un certain nombre de concepts employés «quelque peu en vrac $\gg$ dans les ouvrages sur les mouvements syndicaux : organisations ou associations volontaires, institutions sociales ou économiques, groupes d'intérêts ou de pression.

Selon eux, le syndicalisme au Québec agit principalement au plan économique. Mais lorsqu'il pose des problèmes économiques de plus en plus généraux, il se situe à l'endroit où il $y$ a recouvrement des secteurs économiques et politiques.

Même si le syndicalisme est surtout de type contestant au Québec, les auteurs ne manquent pas de souligner les liens qu'il entretient avec le mouvement coopératif et même avec un parti politique (le NPD appuyé surtout par la Fédération des travailleurs du Québec).

MM. Dofny et Bernard dégagent trois tendances du syndicalisme au Québec: un syndicalisme traditionnel, centré sur l'artisanat industriel et de métier; un syndicalisme moderne centré sur la grande industrie et un nouveau syndicalisme recrutant surtout ses adhérents dans les services publics et les emplois de type tertiaire dans l'industrie. Ils étudient ensuite les causes des principaux changements structurels des appareils syndicaux de chacune des centrales (Confédération des syndicats nationaux et FTQ) à la lumière des trois grandes catégories des différents syndicats.

On peut se demander, comme dans cette étude, ce qu'il adviendra des deux organisations syndicales: "hésitantes face aux choix d'un modèle économique pour le Québec, sièges de conflits entre gompériens, anarcho-syndicalistes, tradeunionistes et marxistes, peut-on concevoir qu'elles aboutissent un jour à une unité d'action?»

Jacques LAFRENIERE 